\title{
Pengembangan Perangkat Pembelajaran Berbasis Pendekatan Kontekstual Untuk Siswa SMA
}

\author{
Faderina Komisia $^{1}$, Maria Benedikta Tukan ${ }^{2 *}$, Maria Aloisia Uron Leba ${ }^{3}$ \\ 1,2,3 Program Studi Pendidikan Kimia, Universitas Katolik Widya Mandira \\ *e-mail: mariabenediktatukan@gmail.com \\ (Received: 08-02-2021; Reviewed: 09-02-2021; Accepted: 11-02-2021)
}

\begin{abstract}
Abstrak
Penelitian ini bertujuan untuk menghasilkan produk berupa perangkat pembelajaran berbasis pendekatan kontekstual untuk siswa SMA dan mendeskripsikan respon siswa dalam pembelajaran yang berbasis kontekstual. Penelitian ini adalah penelitian pengembangan. Lokasi penelitian ini dilaksanakan di SMA Seminari St. Rafael, Oepoi, Kupang. Desain Penelitian ini adalah research and development. Penelitian ini berfokus pada pengembangan perangkat berupa Rencana Pelaksanaan Pembelajaran, Bahan Ajar Siswa, dan Lembar Kerja Siswa berbasis pendekatan kontekstual. Perangkat pembelajaran divalidasi oleh pakar dan kemudian diujicobakan. Variabel yang diidentifikasi adalah validitas dan respon siswa terhadap perangkat yang telah dikembangkan. Capaian dari penelitian ini dapat disimpulkan bahwa RPP, LKS, dan BAS berkategori baik. Selain itu, respon siswa sangat positip.
\end{abstract}

Kata kunci: pengembangan perangkat, kontekstual, siswa

\section{Abstract}

This study aims to produce a product in the form of a contextual approach based learning tool for high school students and to describe the student's response in contextual-based learning. This research is a development research. The location of this research was carried out at St. Seminary Senior High School. Rafael, Oepoi, Kupang. This research design is research and development. This research focuses on developing tools in the form of lesson plans, student teaching materials, and student worksheets based on a contextual approach. Learning tools are validated by experts and then tried out. The variables identified were the validity and responses of students to the tools that have been developed. The results of this study can be concluded that the lesson plans, worksheets, and BAS are in good categories. In addition, student responses were very positive.

Keywords: device development, contextual, students

\section{Pendahuluan}

Mata pelajaran kimia adalah cabang dari ilmu sains dimana mempelajari pengetahuan fakta, konsep, prinsip, hukum, atau teori namun merupakan tahap penemuan, yang mana diharapkan agar siswa memperoleh pengalaman melalui pengalaman belajarnya di kelas (Rahmawati et al; 2019). Pada hakikatnya dalam pembelajaran siswa dituntut untuk terlibat aktif, mampu berpikir kritis dan kreatif (Hernaeny \& Alfin, 2016) hal ini dikarenakan ilmu kimia yang disajikan oleh guru dapat dimengerti oleh peserta didik jika diberi kesempatan untuk mengemukakan pendapat atau pandangannya, sehingga sangat diperlukan metode, pendekatan serta perangkat pembelajaran yang dapat memperlihatkan peran aktif siswa di kelas. Dalam pelaksanaan pembelajaran, pendidik membutuhkan media pembelajaran berupa perangkat pembelajaran yang utuh atau lengkap (Kurniawan, 2018). Menurut Budiarso (2017), perangkat pembelajaran yang baik adalah harus melewati tahapan validasi ahli/pakar dan direvisi berdasarkan hasil ujicoba lapangan. Menurut Syahbana, (2012), fungsi perangkat pembelajaran adalah meringankan pendidik dalam menjalankan 
pembelajaran di kelas serta pengalaman kegiatan belajar mengajar yang bervariatif demi mencapai tujuan pembelajaran yang diinginkan. (Anisah \& Mahardika, 2016).

Dalam pembelajaran berbasis kontesktual siswa diajarkan cara-cara mencari dan mengorganisasi data dan melatih mahasiswa untuk terampil mengembangkan berbagai konsep (Basya et al; 2019). Berdasarkan hasil observasi di lapangan dan wawancara khusus dengan guru mata pelajaran IPA di SMA Seminari St. Rafael, Oepoi, Kupang untuk materi Asam Basa sering tidak dilakukan kegiatan praktikum karena ketiadaan bahan ajar/perangkat pembelajaran, juga didukung ketiadaan alat-alat laboratorium yang mana menunjang kegiatan praktikum siswa. Hal ini menyebabkan kesulitan bahkan miskonsepsi pada siswa. Akibatnya siswa tidak dilatihkan keterampilan-keterampilan sains dan menggunakan keterampilan tersebut untuk membangun atau menemukan konsep/prinsip/solusi dari permasalahan yang diajukan dalam pembelajaran (Wikansari, 2017).

Dalam penelitian ini pengembangan perangkat pembelajaran yang dilakukan mengacu pada model four D yang terdiri atas 4 tahap, yaitu tahap pendefinisian (Define), perancangan (Design), pengembangan (Develop), dan penyebaran (Dessiminate). Namun demikian dalam penelitian ini hanya akan dilakukan sampai tahap ketiga (Develop). Model ini dipilih karena tampak lebih terperinci tahapan-tahapannya, sistematis dan cocok untuk mengembangkan perangkat pembelajaran yang berbasis kontekstual. Modifikasi dari model four-D dapat dimodifikasi atau dikerjakan dengan cara (a) mengurutkan kegiatan secara lebih terarah atau terjadwal (b) menggunakan beberapa konsep atau istilah penting yang luas pengertiannya yang dapat digunakan oleh pendidik di lapangan (c) sebagai tambahan beberapa kegiatan yang penting dalam proses penentuan media yang akan dikembangkan atau dilakukan, (d) mengurangi tahap atau kegiatan yang dianggap tidak perlu. Kelebihan dari model four-D adalah: (a) dijadikan alas/dasar sebagai pengembangan media berupa perangkat pembelajaran (b) penjelasannya secara singkat dan berurutan (c) melibatkan penilaian beberapa pakar/ahli sebelum proses ujicoba sebenarnya di lapangan dan pembelajaran telah melewati proses revisi berdasarkan penilaian, saran dan masukan para ahli (Rahayu \& Fahinu, 2019).

Berdasarkan uraian tersebut, maka peneliti tertarik untuk melakukan penelitian ini, sehingga nantinya produk dari penelitian ini berupa perangkat pembelajaran yang dihasilkan dapat dipergunakan oleh para guru kimia di SMA St. Rafael Oepoi, Kupang, Nusa Tenggara Timur. Selain itu, diharapkan melalui penelitian ini peserta didik terlibat aktif mencari makna dari tugastugas yang berupa menemukan permasalahan kimia yang menarik, menemukan informasi dan juga membuat kesimpulan, secara aktif memilih strategi yang tepat, menyusun, merancang, melakukan penyelidikan, mengajukan pertanyaan, dan mengeneralisasi atau menyimpulkan kesimpulan tentang penyelesaian suatu masalah kimia, dan mengaitkan konsep kimia yang dipelajari dengan situasi kehidupan yang relevan dengan peserta didik.

\section{Metode}

Penelitian ini menggunakan model pengembangan 4D yang terdiri atas 4 tahap utama yaitu: (a) Define (Pendefinisian), (b) Design (Perancangan), (c) Develop (Pengembangan), dan (d) Disseminate (Penyebaran). Secara garis besar keempat tahap tersebut meliputi tahap pendefinisian (Define), tujuan tahap ini adalah menetapkan dan mendefinisikan syarat-syarat pembelajaran yang diawali dengan analisis tujuan dari batasan materi yang dikembangkan perangkatnya; tahap perencanaan (Design), tujuan tahap ini adalah menyiapkan prototipe perangkat pembelajaran; tahap 
pengembangan (Develop), tujuan tahap ini adalah untuk menghasilkan perangkat pembelajaran yang sudah direvisi berdasarkan masukan dari pakar. Tahap ini meliputi: (a) validasi perangkat oleh para pakar diikuti dengan revisi, dimana langkah berikutnya adalah uji coba lebih lanjut dengan siswa yang sesuai dengan kelas sesungguhnya; tahap penyebaran (Disseminate). Pada tahap ini merupakan tahap penggunaan perangkat yang telah dikembangkan pada skala yang lebih luas, namun dalam penelitian ini hanya sampai pada tahap pengembangan (develop)

Subjek penelitian ini adalah siswa kelas XI SMAK St. Rafael, Oepoi Kupang. Penelitian ini dilaksanakan di semester ganjil tahun ajaran 2020/2021. Dalam penelitian ini yang merupakan variabel penelitian adalah validitas media pembelajaran yakni perangkat pembelajaran serta juga tanggapan peserta didik pada pengajaran berbasis kontekstual materi asam basa. Instrumen yang digunakan yakni sebagai berikut: (1) Lembar Validasi RPP, Lembar Validasi LKS, dan Lembar Validasi BAS dan Lembar Angket Respon Siswa. Teknik pengumpulan data yakni menggunakan teknik validasi dan pemberian angket/kuisioner. Kelayakan media berupa perangkat pembelajaran dinilai oleh para pakar. Perangkat berupa RPP, LKS, dan BAS dilakukan validasi oleh pakar pendidikan. Data hasil penilaian dianalisis secara deskriptif. Penentuan penilaian adalah skor rerata $(P)$ yang diberikan oleh validator atau ahli atau praktisi, kemudian disesuaikan dengan kriteria penilaian perangkat pembelajaran ( Sudjana, 2011). Angket respon siswa digunakan untuk mengetahui pendapat siswa atau respon siswa (Ade Mutia et al; 2020) pada media berupa perangkat yang telah dibuat. Tanggapan peserta didik dihitung atau dianalisis secara deskriptif dengan persentase sebagai berikut:

$$
P=\frac{\sum R}{\sum N} \times 100 \%
$$

\section{Hasil dan Pembahasan}

Dalam penelitian ini pengembangan perangkat pembelajaran dilakukan dengan mengacu pada model 4D yaitu tahap pendefinisian (Define), perancangan (Design), pengembangan (Develop), dan penyebaran (Dessiminate). Namun demikian dalam penelitian ini hanya akan dilakukan sampai tahap ketiga (Develop). Tahap Pendefinisian (define) adalah menetapkan dan mendefinisikan syarat-syarat pembelajaran. Tahap ini dilakukan dengan melakukan analisis tujuan dalam batasan materi pelajaran yang akan dikembangkan perangkatnya. Ada lima langkah pokok dalam tahap ini, yaitu 1) analisis kurikulum, 2) analisis siswa, 3) analisis tugas, 4) analisis konsep, dan 5) perumusan tujuan pembelajaran. Selanjutnya adalah tahap perancangan (Design), pada tahap ini dilakukan perencanaan bentuk dasar perangkat pembelajaran meliputi RPP, LKS, dan Bahan Ajar Siswa. Rencana Pelaksanaan Pembelajaran disusun untuk setiap pertemuan yang terdiri atas tiga Rencana Pelaksanaan Pembelajaran, yang masing-masing dirancang untuk pertemuan $2 \times 45$ menit. Lembar kegiatan siswa (LKS) merupakan panduan siswa yang digunakan untuk memahami materi dan melakukan kegiatan percobaan. Bahan ajar disusun dari beberapa literatur terkait dengan bab materi mengenai Asam Basa. Untuk tahap pengembangan (Develop) bertujuan untuk menghasilkan perangkat pembelajaran yang memenuhi syarat, valid, dan sahih (reliabel). Tahap ini meliputi (1) validasi perangkat pembelajaran, (2) revisi, dan (3) ujicoba.

Perangkat pembelajaran yang telah dikembangkan sebelum diujicobakan di dalam kelas terlebih dahulu divalidasi oleh 2 orang validator (validasi pakar), yaitu Anselmus Boy Baunsele, M.Sc dan Yustina Dwisofiani Lawung, M.Pd. Adapun hasil penilaian RPP oleh validator yang meliputi aspek identitas (4.0), tujuan $(3,25)$, model pembelajaran yang dipilih $(4,0)$, sarana dan sumber belajar $(3,25)$, langkah pembelajaran $(3,67)$, evaluasi $(4,0)$ dan keterbacaan $(3,5)$ dengan 
nilai rata-rata 3,67 dan reliabilitas $86,67 \%$. Berdasarkan pemaparan di atas maka RPP yang dibuat dan direvisi ini dapat digunakan di kelas terkhusus pada mata pelajaran kimia dan menjadi rujukan bagi guru/pengembang lain untuk mengembangkan RPP berorientasi pada pembelajaran yang berbasis kontekstual. LKS merupakan panduan siswa di dalam melakukan aktivitas penyelidikan konsep/prinsip/solusi di dalam kegiatan pembelajaran. Dari hasil validasi pakar diperoleh informasi bahwa kualitas LKS ini berkategori baik untuk seluruh aspek penilaian, sehingga dapat digunakan dalam pembelajaran kimia. Hasil penilaian LKS oleh validator yang terdiri dari aspek organisasi LKS $(3,63)$, penjabaran rangkaian materi $(3,5)$, prosedur $(3,42)$, pertanyaan $(3,67)$, dan alat dan bahan $(3,0)$ mendapatkan nilai rata-rata 3,44 dengan reliabilitas 78,94\%. Berdasarkan pemaparan di atas maka LKS yang telah dikembangkan ini dapat digunakan di sekolah terkhusus pada mata pelajaran kimia kompetensi dasar menguasai asam basa dan menjadi rujukan bagi guru/peneliti lain untuk mengembangkan LKS yang berorientasi pada pembelajaran berbasis kontekstual.

Bahan Ajar Siswa (BAS) merupakan perangkat yang berfungsi sebagai yang dipergunakan oleh siswa sebagai panduan belajar baik di sekolah atau di kelas maupun belajar mandiri. BAS yang telah dikembangkan ini dinilai oleh dua orang pakar atau validator. Dari hasil validasi pakar diperoleh informasi bahwa kualitas BAS ini berkategori sangat baik untuk seluruh aspek penilaian, sehingga dapat digunakan dalam pembelajaran kimia. Hasil penilaian BAS oleh validator yang terdiri dari aspek pendahuluan $(4,0)$, isi $(3,50)$, karakteristik sub konsep $(3,50)$, penutup $(3,50)$, dan penjabaran konsep $(3,50)$ mendapatkan skor perolehan sebesar 3,60 dengan reliabilitas 77,77\%. Berdasarkan pemaparan di atas maka BAS yang telah dikembangkan ini dapat digunakan di sekolah terkhusus pada mata pelajaran kimia serta kompetensi dasar menguasai asam basa dan menjadi rujukan bagi guru/peneliti lain untuk mengembangkan BAS yang berorientasi pada pembelajaran yang berbasis kontekstual.

Pemberian angket respon siswa, bertujuan menginformasikan tanggapan peserta didik dalam mengikuti pengajaran yang berbasis kontekstual. Pada pembelajaran yang berbasis kontekstual menunjukkan bahwa respon siswa terhadap komponen pembelajaran seperti materi/isi pelajaran, bahan ajar siswa, lembar kegiatan siswa, suasana belajar, dan cara guru mengajar sebesar 100\% siswa menyatakan tertarik. Respon siswa terhadap keterbaruan komponen pembelajaran seperti materi/isi pelajaran, buku ajar siswa, lembar kegiatan siswa, suasana belajar, dan cara guru mengajar sebesar $100 \%$ siswa menyatakan komponen-komponen tersebut baru. Respon siswa terhadap bahasa dalam buku, materi/isi buku, contoh-contoh soal, LKS dan cara guru mengajar adalah $100 \%$ siswa merasa mudah untuk dipahami. Tanggapan peserta didik dalam pengajaran yang berbasis kontekstual adalah sebesar $86 \%$ siswa menyatakan berminat dalam mengikuti pelajaran yang berbasis kontekstual, sedangkan $14 \%$ siswa lainnya menyatakan kurang berminat. Sebesar 93\% siswa menyatakan penjelasan guru pada saat kegiatan belajar mengajar berlangsung dan bimbingan guru pada saat siswa menemukan konsep melalui eksperimen adalah jelas, sedangkan 7\% siswa lainnya menyatakan kurang jelas. Respon siswa pada aspek kemudahan siswa dalam menjawab soal-soal pada lembar kerja siswa adalah sebesar $100 \%$ siswa menyatakan mudah untuk menjawab butir soal pada lembar kerja siswa. Respon siswa terhadap pembelajaran yang berbasis kontekstual disambut positif oleh siswa karena siswa diberi kebebasan berpendapat, memberikan permasalahan, berdiskusi dan menyelesaikan permasalahan secara mandiri.

Berdasarkan perolehan data di atas diperoleh kesimpulan bahwa dapat membantu guru meningkatkan hasil pembelajaran kimia, serta peserta didik diberi kebebasan berpendapat, memberikan permasalahan, berdiskusi, dan menyelesaikan permasalahan secara mandiri. Hal ini juga didukung oleh penelitian Tati et al; (2013) yang menyatakan berdasarkan hasil angket, respon 
siswa sangat baik terhadap pelaksanaan pembelajaran yang berbasis kontekstual. Siswa tertarik karena dengan pembelajaran konstekstual siswa diberi kebebasan berpendapat, memberikan permasalahan, berdiskusi, dan menyelesaikan permasalahan secara mandiri. Hal ini juga didukung oleh hasil penelitian Lamapaha (2017) yang menyatakan bahwa melalui penerapan pendekatan kontekstual memberikan pengaruh yang positif terhadap hasil belajar siswa, melalui strategi ini siswa merasa senang dalam mengikuti kegiatan pembelajaran serta motivasi belajar siswa dapat terjaga selama kegiatan pembelajaran berlangsung.

\section{Kesimpulan}

Kesimpulan dari penelitian ini dapat ditulis sebagai berikut: Produk yang dihasilkan dalam penelitian ini yaitu dokumen berupa perangkat pembelajaran berbasis kontekstual. Perangkat pembelajaran yang dikembangkan dinyatakan layak untuk dipergunakan di sekolah. Hal ini terbukti dari penilaian para validator yakni RPP yang telah dibuat oleh peneliti berkategori sangat baik; Lembar kegiatan siswa yang dibuat oleh peneliti berkategori baik; Bahan Ajar Siswa yang dibuat oleh peneliti juga berkategori baik, sehingga dapat ditarik suatu simpulan dari penelitian ini bahwa pengembangan perangkat pembelajaran yang berbasis kontekstual layak untuk digunakan dalam pelaksanaan pembelajaran di sekolah. Selain itu, respon siswa terhadap implementasi perangkat pembelajaran yang digunakan di kelas bernilai positif dan baik.

\section{Ucapan Terima Kasih}

Pelaksanaan penelitian ini tentu tidak terlepas dari peran banyak orang. Untuk itu penulis menghaturkan banyak ucapan terima kasih kepada Pimpinan/Rektor Unwira Kupang yang telah memfasilitasi penulis dalam hal dukungan dana serta Lembaga Penelitian dan Pengabdian Masyarakat (LPPM) Universitas Katolik Widya Mandira, Kupang-Nusa Tenggara Timur yang telah berupaya memfasilitasi dan membantu penulis dalam penelitian ini.

\section{Referensi}

Ade Mutia, Hadinugrahaningsih, T., \& Budi, S. (2020). Pengaruh Model Pembelajaran Inkuiri Terbimbing dengan Pendekatan Berbasis Kontekstual (CBA) terhadap Literasi Kimia Peserta Didik Kelas XI MIPA SMA Negeri Jakarta pada Materi Hidrolisis Garam. JRPK: Jurnal Riset Pendidikan Kimia, 10(1), 1-8. https://doi.org/10.21009/jrpk.101.01

Anisah, A., Wati, M., \& Mahardika, A. I. (2016). Pengembangan Perangkat Pembelajaran Getaran Dan Gelombang Dengan Model Inkuiri Terstruktur Untuk Siswa Kelas VIIIA SMPN 31 Banjarmasin. Berkala Ilmiah Pendidikan $\quad$ Fisika, 4(1), https://doi.org/10.20527/bipf.v4i1.1008

Basya, Y. F., Rifa'i, A. F., \& Arfinanti, N. (2019). Pengembangan Mobile Apps Android Sebagai Media Pembelajaran Matematika Berbasis Pendekatan Kontekstual Untuk Memfasilitasi Pemahaman Konsep. Jurnal Pengembangan Pembelajaran Matematika (JPPM) /Vol I No 1 Februari 2019 PENGEMBANGAN, I(1), 1.

Budiarso, A. S. (2017). Analisis Validitas Perangkat Pembelajaran Fisika Model Inkuiri Terbimbing untuk Meningkatkan Hasil Belajar Siswa SMA pada Materi Listrik Dinamis. Jurnal Edukasi, 4(2), 15. https://doi.org/10.19184/jukasi.v4i2.5204 
Gusriani, A., \& Yanti, Z. P. (2020). Efektivitas Pengembangan Perangkat Pembelajaran Berbasis Pendekatan Kontekstual Pada Materi Menulis Resensi Siswa Sma 1 Lengayang. Kode: Jurnal Bahasa, 9(3).

Hernaeny, U., \& Alfin, E. (2016). Pengaruh Strategi Pembelajaran Elaborasi terhadap Hasil Belajar Matematika ditinjau dari Motivasi Belajar. Formatif: Jurnal Ilmiah Pendidikan MIPA, 5(3). https://doi.org/10.30998/formatif.v5i3.644

Hidayat, T., \& Syahidin, S. (2019). Inovasi Pembelajaran Pendidikan Agama Islam Melalui Model Contextual Teaching And Learning Dalam Meningkatkan Taraf Berfikir Peserta Didik. Jurnal Pendidikan Agama Islam, 16(2), 115-136. https://doi.org/10.14421/jpai.2019.162-01

Kurniawan, D. (2018). Komunikasi Model Laswell Dan Stimulus-Organism-Response Dalam Mewujudkan Pembelajaran Menyenangkan. Jurnal Komunikasi Pendidikan,2(1), 60. https://doi.org/10.32585/jkp.v2i1.65

Lamapaha, Y. F. (2017). Pengembangan lembar kerja siswa berbasis kontekstual berorientasi penalaran saintifik. Jurnal Pendidikan Matematika Dan Sains, 5(1). https://doi.org/10.21831/jpms.v5i1.13541

Marselina, S. (2018). Peningkatan Keterampilan Menulis Karya Ilmiah Melalui Strategi Belajar Kooperatif Tipe Group Investigation Siswa Kelas Xi Man I Kota Sungai Penuh. Jurnal IlmiahPendidikan Bahasa Dan Sastra Indonesia,4(1), 14-21. Retrieved from http://www.antaranews.com/berita/330125/lipi-

Ningtyas, P K, Hayuni Retno Widarti, M. S. I. (2019). Pengembangan Bahan Ajar dengan Pendekatan STEM PjBL Berbasis Kontekstual Pada Materi Asam dan Basa Untuk Siswa Kelas XI SMA/MA. SKRIPSI Jurusan Kimia-Fakultas MIPA UM, (November), 373-381. Retrieved from http://karyailmiah.um.ac.id/index.php/kimia/article/view/79057

Pradianti, D., Wasis, W., \& Agustini, R. (2017). Pengembangan Perangkat Pembelajaran Fisika Model Inkuiri Terbimbing Untuk Melatihkan Kinerja Ilmiah Siswa. JPPS (Jurnal Penelitian Pendidikan Sains), 4(2), 672. https://doi.org/10.26740/jpps.v4n2.p672-680

Rahayu, O., Anggo, M., \& Fahinu, F. (2019). Pengaruh Pembelajaran Berbasis Masalah Dengan Pendekatan Metakognisi Terhadap Kemampuan Pemecahan Masalah Matematika Ditinjau Dari Kemampuan Awal Matematika Siswa SMPN 2 Kendari. Jurnal Pendidikan Matematika, 9(2), 150. https://doi.org/10.36709/jpm.v9i2.5865

Rahmawati, T. D., Wahyuningsih, W., \& Dua Getan, M. A. (2019). Pengaruh Model Pembelajaran Contextual Teaching And Learning Terhadap Hasil Belajar Matematika Siswa. JINoP (Jurnal Inovasi Pembelajaran), 5(1), 83. https://doi.org/10.22219/jinop.v5i1.8021

Setiawan, M. A., Suharto, T., \& Slamet, R. (2017). Pengaruh Pembelajaran Kimia Dengan Pendekatan Inkuri Berbasis Kegiatan Laboratorium Terhadap Tingkat Kreativitas Siswa SMA Pada Materi Larutan Asam Basa (Quasi Eksperimen Di Sma Don Bosco Ii Jakarta). JRPK: Jurnal Riset Pendidikan Kimia, 4(1), 214-227. https://doi.org/10.21009/jrpk.041.08 
Suhartini, E., Supardi, Z. A. I., \& Agustini, R. (2017). Pengembangan Perangkat Pembelajaran Model Inkuiri Terbimbing Berbantuan Teknik Mind Mapping Untuk Meningkatkan Penguasaan Konsep Dan Kemampuan Berpikir Kreatif Siswa SMP. JPPS (Jurnal Penelitian Pendidikan Sains), 5(2), 892. https://doi.org/10.26740/jpps.v5n2.p892-902

Syahbana, A. (2012). Pengembangan Perangkat Pembelajaran Berbasis Kontekstual untuk Mengukur Kemampuan Berpikir Kritis Matematis Siswa SMP. Edumatica, 2(2), 17-26.

Tambunan, N. (2016). Pengaruh Strategi Pembelajaran dan Minat Belajar Terhadap Kemampuan Berpikir Kreatif Matematis Siswa. Formatif: Jurnal Ilmiah Pendidikan MIPA, 6(3). https://doi.org/10.30998/formatif.v6i3.993

Tati, T., Zulkardi, Z., \& Hartono, Y. (2013). Pengembangan Perangkat Pembelajaran Berbasis Kontekstual Pokok Bahasan Turunan Di Madrasah Aliyah Negeri 3 Palembang. Jurnal Pendidikan Matematika, 3(1). https://doi.org/10.22342/jpm.3.1.323.

Wikansari, R. (2017). Hubungan persepsi pada lingkungan sekolah. Jurnal Komunikasi Pendidikan, 1(1), 19-32. 